\title{
EVALUATION OF THE TECHNOLOGICAL CHARACTERISTICS OF CLAY WHEN ADDING BUILDING MATERIALS TO MANUFACTURE STRUCTURAL PRODUCTS WITHOUT IMPLEMENTING A SINTERING PROCESS
}

\author{
EVALUACIÓN DE LAS CARACTERÍSTICAS TECNOLÓGICAS DE UNA \\ ARCILLA AL ADICIONARLE MATERIALES DE CONSTRUCCIÓN PARA \\ FABRICAR PRODUCTOS ESTRUCTURALES SIN EJECUTAR EL PROCESO DE \\ SINTERIZADO
}

Leonardo Cely Illera', Claudia Vanessa Cely Illera², Keila Anteliz Contreras ${ }^{3}$

Fecha de recepción: 28 de marzo de 2016

Fecha de revisión: 17 de mayo de 2016

Fecha de aprobación: 2 de junio de 2016

Referencia: L. Cely Illera, C. V. Cely Illera, K. Anteliz Contreras (2016). Evaluation of the technological characteristics of clay when adding building materials to manufacture structural products without implementing a sintering process. Ciencia e Ingeniería Neogranadina, 26 (2), pp. 5-20, DOl: http://dx.doi.org/10.18359/rcin.1811

\begin{abstract}
This research presents a study on the effect of the addition of materials such as sand, cement, and lime on a red clay, with the aim of improving its technological characteristics and avoiding the cooking process. The results of a standard paste were compared with the values thrown in different formulations; the mechanical performance and physical properties of the material are improved, increasing the dry densification and with a decrease in the pressability index. The results showed that adding these materials to produce clay increases the flexural strength between $16,9 \%$ and $35,5 \%$ and that there is a reduction in dry contraction of around $8,3 \%$, being F7

\footnotetext{
1. Environmental Eng., MSc. Materials Science and Technology, Architecture Research Group and Alternative Materials (GRAMA), Universidad Francisco de Paula Santander, Norte de Santander, Cúcuta, Colombia, leonardocely@ufps.edu.co

2. Biotechnological Eng., MSc. Engineering Project Management, Bournemouth University, Bournemouth-UK. i7951451@bournemouth.ac.uk

3. Industrial Eng., Universidad Nacional Abierta y a Distancia, Pamplona, Colombia, keilaac@unad.edu.co
} 
the formulation that performed the best. These data contribute to the development of ceramic products with added value to be used in various technological applications without sintered material and reducing the energy consumption and pollution that these processes produce.

Key words: densification, bending, porosimetry, cement, lime.

\section{RESUMEN}

El trabajo hace un estudio sobre el efecto que ejerce la adición de materiales como arena, cemento y cal a una arcilla roja, con el objetivo de mejorar las características tecnológicas y eliminando el proceso de cocción. Se compararon los resultados de una pasta standard, con los valores arrojados en diferentes formulaciones, se mejora el desempeño mecánico y propiedades físicas del material, aumentando la densificación en seco y disminuyendo el índice de prensabilidad. Los resultados demostraron que la adición de estos materiales a la arcilla producen incrementos de resistencia mecánica a la flexión entre el 16,9\% hasta un 35,5\% y una reducción en su contracción en seco de alrededor del 8,3\%, siendo la formulación F7 la que obtuvo los mejores resultados. Estos datos contribuirán al desarrollo de productos cerámicos con valor agregado, para ser usados en diversas aplicaciones tecnológicas sin necesidad de sinterizar el material y disminuyendo el gasto energético y la contaminación que estos procesos producen.

Palabras claves: densificación, flexión, porosimetría, cemento, cal.

\section{INTRODUCTION}

The production process of clay-based products ranges from the exploitation of raw materials to packaging, storage, and distribution of the same. This process takes many stages where maintenance costs, production, and human resources among others are generated making companies increase their monthly development cost and, in consequence, the cost of goods considerably increases when going on sale [1-2].

This means that today the aim is to make products that do not generate high production costs or that increase the cost-benefit ratio at each stage of the production chain; the preparation, forming, drying, and burning stages of a product bill the highest production costs in the process [2]. This is the reason why studies all around the world aim to find a way to manufacture different products with a higher profit at a lower cost creating higher benefits for the industry.

Nowadays, the city of San José de Cúcuta and its metropolitan area has grown industrially in the ceramic sector due to its excellent clays, being this the reason why construction materials are made and exported to various cities. In this region, we can find clays with large mineralogical, chemical, and physical properties that make it a pioneer in the manufacture of construction products [3]. These products acquire their strength through a heat treatment known as sintering which starts at $800{ }^{\circ} \mathrm{C}$ and continues up to 
temperatures of about $1200^{\circ} \mathrm{C}$, generating large energy consumption, which means spending considerable volumes of fuel (fossil, firewood, biomass, etc.) increasing not only the cost of the product but also generating overspending of natural resources.

This is reason why this work is presented; this is an investigation in order to find a new product. In this study, the transformation of a clay (without being sintered) is exposed which is mixed with sand (dimensional control material), cement (stabilizing agent), and lime (plasticizer and control degassing) and thus observe if it is found between international standards for cooked construction materials, in addition to manufacturing a product that is beneficial to nature as it does not generate the deterioration of natural resources.

\section{MATERIALS AND METHODS}

\subsection{Materials}

The materials used in this research were materials commonly used for construction as sand, cement, lime, and clay. Considering that the base of the product produced is clay, this was mineralogical, chemically and physically characterized; this is the material amalgam mix, being the most important part.

Sand, cement, and lime are accompanying materials; for this reason, the materials used are commercially available and they received a check by attributes, in order not to outline the use of these and in the future to use any brand available on the market. In addition, as the product is not synthesized and the process is semi-dry, there was no need to characterize these materials. A brief description of the materials used in the research follows:
Clay. It is reddish hue, a plastic texture material, which comes from the Guayabo formation.

Sand. It is a granular material, of yellow color and with no impurities visually detected.

Cement. It is a gray hue material called Portland Cement Type I, from the company CEMEX Cucuta.

Lime. It is an alkaline substance of a white colour consisting of calcium oxide.

\subsection{Methods}

1.2.1 Methods used for mineralogical and chemical identification of Clay

- X-ray diffraction. The mineralogical composition of the samples was performed by X-ray diffraction (XRD) in a brand powder diffractometer Bruker D8 Advance model under working conditions from $0^{\circ}$ to $40^{\circ}$ degrees to 2 , with a rate of sweeping steps. The diffractogram oriented natural sample has been obtained.

- Chemical analysis. The chemical composition was determined by X-ray fluorescence (XRF) with reference to ASTM C323-56 "Standard Test Methods for chemical analysis of white clays" standard, obtaining the mass percentage of oxides present, this was done in a computer equipment $X$-ray fluorescence Axios Panalytica [4].

\subsubsection{Physical measurements of the clay sample}

- Sieve analysis by hydrometer $152 \mathrm{H}$. Analysis of textural fractions was performed by the technique of hydrometer $152 \mathrm{H}$ [5]. 
- Plasticity. The study of this property was performed by the Pfefferkorn method, by a Pfefferkorn plasticimeter Gabbrielli Technologhy brand (this technique is to determine the plasticity of a clay by compression experienced by a sample in a cylindrical shape, of dimensions determined with different water contents, when hit with a hammer or sledgehammer, of a specific weight and that falls under its own weight, traveling a fixed path).

\subsubsection{Evaluation of technological properties}

- Apparent density. It was determined by the method of mercury intrusion porosimetry using a mark mercurymeter Gabbrielli Technologhy.

- Dry shrinkage. It was determined using a Mitutoyo digital caliper 0,01 mm sensitivity mark [6].

- Mechanical bending resistance. The study of this property has been determined by the NTC 4321-4 standard, using a press pressure (Crometro), all Gabbrielli Technologhy branded [7].

In Figure 1, it is shown some equipment used.

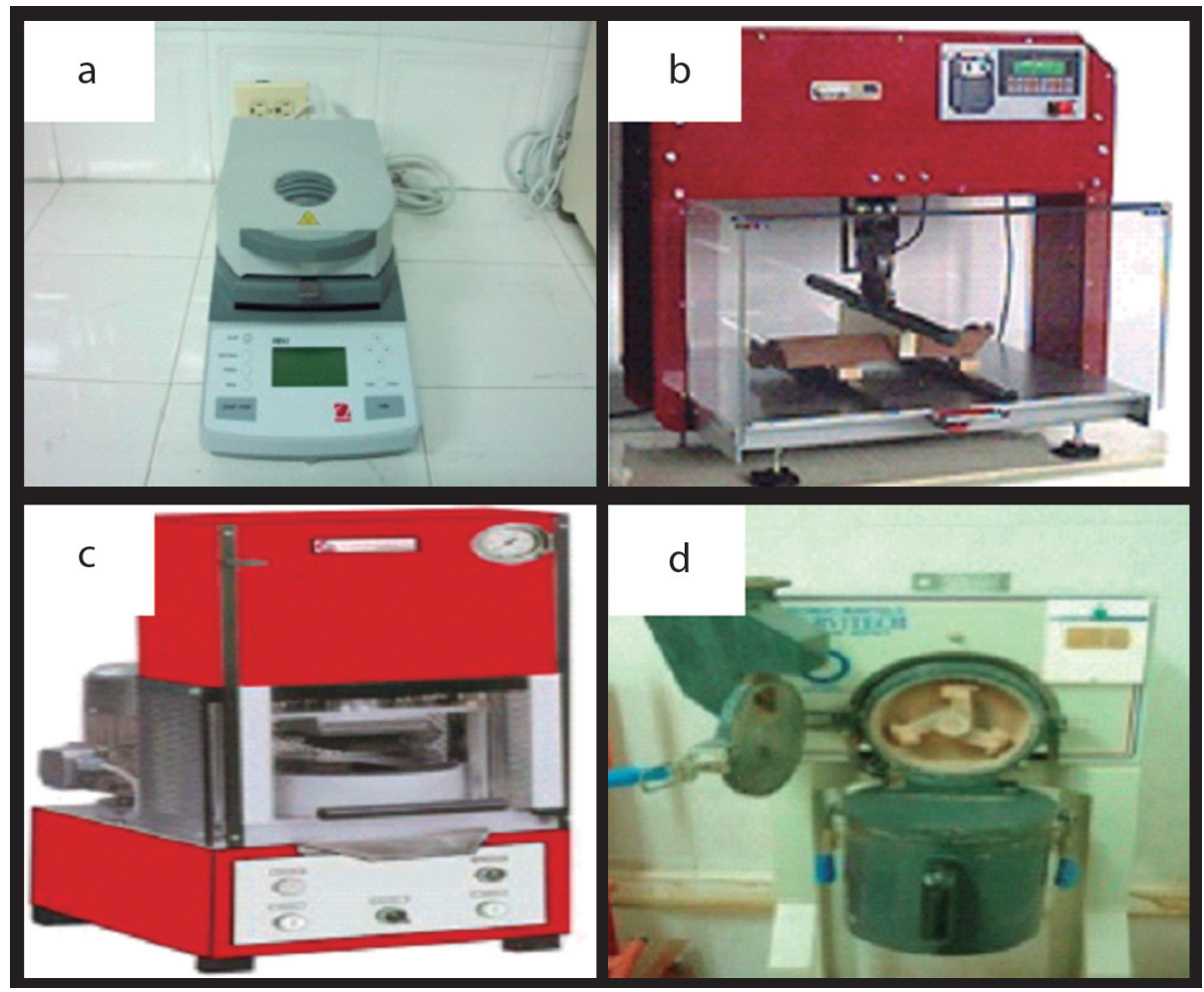

Figure 1. Equipment necessary for the development of the research

(a. Thermobalance; b. Press pressure (Crometro); c. Press; d. Hammer mill).

Source: Center for Ceramic Materials Research -CIMAC- 


\subsubsection{Preparation of formulations}

The clay sample was collected on site, by sampling carried out according to standard 4113-2 NTC. The moisture content was determined in a thermobalance Ohaus MB45; then the drying process was conducted at a temperature of $110 \pm 5^{\circ} \mathrm{C}$ in an oven Gabbrielli Technologhy brand [8-9]. Once the sample was dry, a manual pre-grinding was performed to a size of 10 $\mathrm{mm}$ outer grain. Then, it was taken to a hammer mill, model Servitech mark CT-058 (see Figure 1) in order to obtain a homogeneous and uniform granulometry.

With dry and homogenized materials, it proceeded to perform the grading curve by sieving dry way, following the ASTM D422 standard, in order to observe the distribution of sizes of each material and if necessary a further downsizing for mixing. In Figure 2 the particle size distribution curve is shown [10].
As it was observed, the materials have a particle size of less than $250 \mu \mathrm{m}$, except for the clay that was above this size. For this reason a secondary grinding was performed to the clay and the particle size was reduced to mesh through ASTM $60(250 \mu \mathrm{m})$ and thus the mixing process of the different pastes started. The formulations were obtained after conducting a pilot balanced block design using the four materials. In these mixtures it was taken into account the properties that each material was going to bring to the formulations. The material that will give cohesion to the mix and improve its particle size distribution for its fineness is the clay; to control and reduce the differences in sizes in the shaped product, and to achieve better compaction, sand was added; cement was used as a stabilizing agent and lime was added primarily as a plasticizer to not affect the final properties but also to control outgassing and water evaporation. Accordingly, the different percentages were determined by

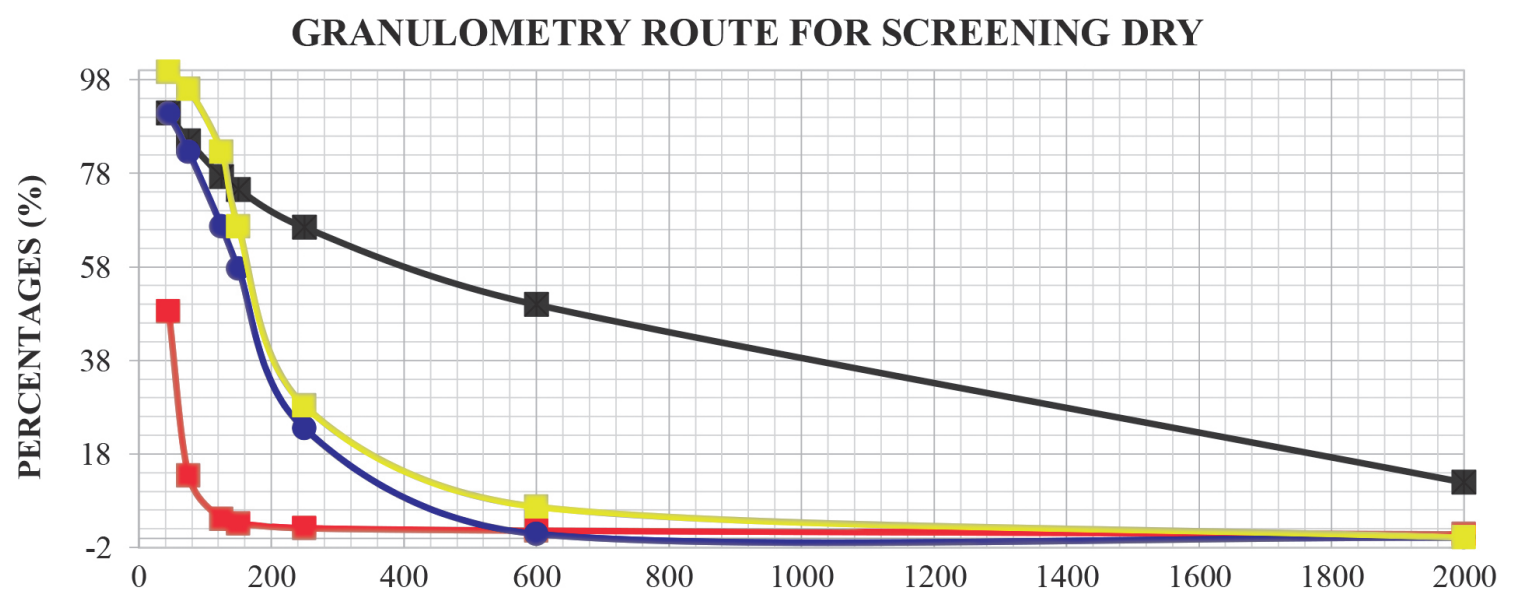

PARTICLE DIAMETER $(\mu \mathrm{m})$
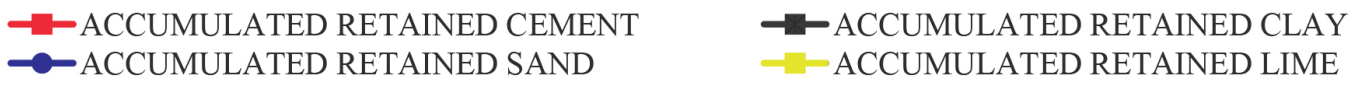

Figure 2. Granulometric curve by dry sieving of the research materials.

Source: The authors 
weight of each formulation. Formulations can be seen in Table 1.

\subsubsection{Test procedure}

The research was conducted in the laboratory, a total of seven formulations were mixed and the development of the mechanical strength was studied; plus a "Standard" paste was mixed, using the most efficient results of similar experiences, which was taken as a reference to compare all results.

With the "Standard" paste, laboratory specimens and specimens at industrial level were held, the test compressive strength for masonry products with vertical drilling (PV) and compared with NTC 4205 standard were performed in order to observe whether they met the international standard [11-17]. The results are shown in Table 2, in which it is detailed that the standard paste in dry conditions has ex- cellent mechanical properties which are above parameters thrown by the standard; it is even above the other classifications both structural and non structural. For this reason, it was taken as reference and this was the starting point for analyzing other dough made.

The preparation process was performed by mixing each of the formulations with dry materials $(<1 \%)$, by manual mixing; each of pasta including the "Standard" was wetted to $6,0 \pm 0,1$ $\%$ by weight, according to the experiences developed and considering the average moisture to form specimens by pressing [18]. They were formed in a laboratory press with rectangular 20-40 T mold, about 200 specimens of at a pressure of 26,17 bars ( $3 \mathrm{MPa}$ ) equivalent to $240 \mathrm{Kg} / \mathrm{cm}^{2}$ specific pressure at industrial level. Specimens of each formulation were taken for various wet tests, the rest were dried in an oven at $110 \pm 5^{\circ} \mathrm{C}$ for $6 \mathrm{~h}$, dried samples corresponding tests were performed [19].

Table 1. Formulations used for research.

\begin{tabular}{|c|c|c|c|c|}
\hline FORMULATION & $\begin{array}{c}\text { CLAY } \\
\text { (MASS \%) }\end{array}$ & $\begin{array}{c}\text { SAND } \\
\text { (MASS \%) }\end{array}$ & $\begin{array}{c}\text { LIME } \\
\text { (MASS \%) }\end{array}$ & $\begin{array}{c}\text { CEMENT } \\
\text { (MASS \%) }\end{array}$ \\
\hline STANDARD & 70,0 & 8,3 & 16,7 & 5,0 \\
\hline F1 & 61,3 & 12,9 & 22,6 & 3,2 \\
\hline F2 & 52,3 & 30,9 & 15,3 & 1,5 \\
\hline F3 & 44,9 & 25,6 & 23,1 & 6,4 \\
\hline F4 & 68,2 & 13,2 & 10,3 & 8,3 \\
\hline F5 & 73,5 & 11,3 & 13,2 & 2,0 \\
\hline$F 6$ & 42,3 & 18,6 & 28,6 & 10,5 \\
\hline$F 7$ & 49,5 & 23,5 & 12,6 & 14,4 \\
\hline
\end{tabular}

Source: The authors. 
Table 2. Comparative results of compressive strength and norm NTC 4205.

\begin{tabular}{|c||c|c||}
\hline \multicolumn{3}{|c|}{ COMPRESSIVE STRENGTH $\left(\mathbf{k g f / \mathbf { c m } ^ { 2 } )}-\mathbf{N T C ~ 4 2 0 5}\right.$} \\
\hline \multirow{3}{*}{ STANDARD } & STRUCTURAL RUBBLE WORK & NO STRUCTURAL RUBBLE WORK \\
\cline { 2 - 3 } & VERTICAL DRILLING & VERTICAL DRILLING \\
\hline \multirow{2}{*}{27,66} & 18,0 & 14,0 \\
\hline
\end{tabular}

Source: Colombian Technical Standard NTC 4205. "Masonry units clay. bricks and ceramic blocks ".

\section{RESULTS AND DISCUSSION}

\subsection{CHARACTERIZATION OF CLAY MATERIAL}

\subsubsection{Mineralogical and chemical study}

As shown in Figure 3, the mineralogical analysis by XRD indicated that the clay has crystal structures such as quartz $\left(26.63^{\circ}\right)$, also has its major peaks associated to kaolinite and illite agreeing with clays found in this region; it also exhibits minor contributions as calcite carbonate $\left(39.3^{\circ}\right)$ [20-21].
According to the results of the chemical analysis set out in Table 3 , the $\mathrm{K}_{2} \mathrm{O}$ content of the sample $(1,63 \%)$ confirms the existence of illitic minerals, plus the low proportion of calcium and magnesium oxides whose values are at $0,22 \%$ and $0,75 \%$ respectively, influencing the characteristics of the material, because with such low values it is indicated a longer cooking range and less pyroplastic deformation if the material is sintered to detail these oxides detail, it is relevant to say that they are in the form of carbonates [22].

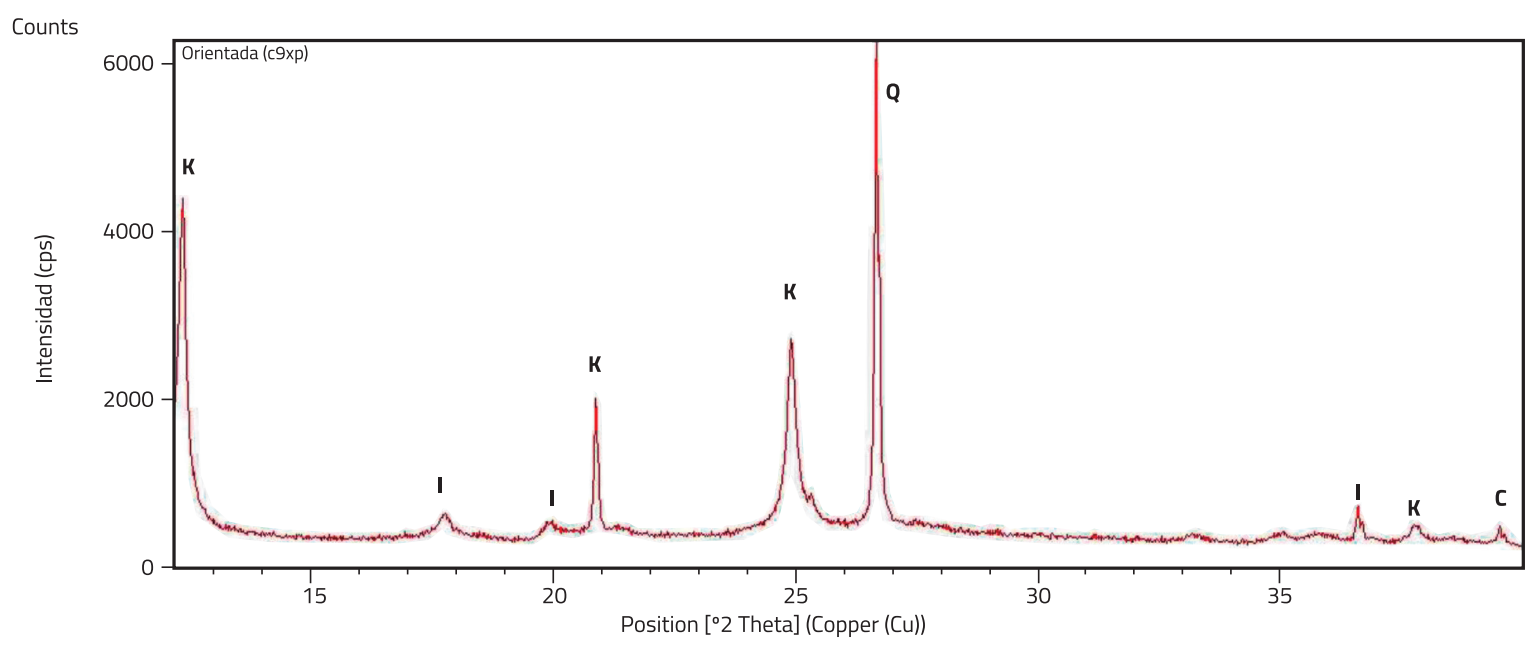

Figure 3. X-ray diffractogram Clay (Q: Quartz; K: Kaolinite; I: Illite; C: Calcite).

Source: UIS x-ray laboratory. 
Meanwhile, the proportion of $\mathrm{Al}_{2} \mathrm{O}_{3}(20,56 \%)$ corroborates the refractory nature of this material and the percentage of $\mathrm{SiO}_{2}(64,87 \%)$ determines the existence of free quartz in varying proportions, which can be excessive and dangerous affecting the technological behavior of clay (physical and mechanical properties). The $\mathrm{Fe}_{2} \mathrm{O}_{3}$ content, with a value of $4,75 \%$, indicates a red baked product. As it can be seen, the value of $\mathrm{SiO}_{2} / \mathrm{Al}_{2} \mathrm{O}_{3}$ molar ratio is within 5,40; making it to provide a high cation exchange capacity (CEC) and an increase in binding energy between the particles characteristic of illitic materials [23].

Table 3. Clay Chemical Composition (FRX).

\begin{tabular}{|c|c|c|}
\hline \multicolumn{3}{|c|}{ COMPOSITION } \\
\hline FORMULA & NAME & MASS \% \\
\hline $\mathrm{SiO}_{2}$ & SILICON OXIDE & 64,87 \\
\hline $\mathrm{Al}_{2} \mathrm{O}_{3}$ & ALUMINUM OXIDE & 20,56 \\
\hline $\mathrm{Fe}_{2} \mathrm{O}_{3}$ & IRON OXIDE & 4,75 \\
\hline $\mathrm{Na}_{2} \mathrm{O}$ & SODIUM OXIDE & 0,15 \\
\hline \hline $\mathrm{K}_{2} \mathrm{O}$ & POTASSIUM OXIDE & 1,63 \\
\hline \hline $\mathrm{CaO}^{2}$ & CALCIUM OXIDE & 0,22 \\
\hline $\mathrm{MgO}^{\mid}$ & MAGNESIUM OXIDE & 0,75 \\
\hline $\mathrm{SO}_{3}$ & TRIOXIDE SULPHUR & 0,04 \\
\hline \multicolumn{2}{|c|}{ LOSS OF IGNITION } & 5,99 \\
\hline \multicolumn{2}{|c|}{ MOLAR RATIO (SIO IAI $_{2} \mathrm{O}_{3}$ ) } & 5,40 \\
\hline
\end{tabular}

Source: CEMEX Laboratory

\subsubsection{Physical study}

The plasticity index showed a value of $28,3 \%$, showing a high plastic behavior, this is due to the mineralogical constitution and the particle size distribution of the material [24], as de- tailed in the results of particle size analysis by hydrometer $152 \mathrm{H}$ (Figure 4). It indicates that the sample is composed largely of clayey-silty fraction $(<2 \mu \mathrm{m})$ with a low percentage of sand [25]. Although the results of similar studies recommend that the soil should be rich in sand, it is better to control this parameter by adding it to each formulation. In addition, the sampled material has this feature with a percentage of $68,93 \%$ clay that generated in the internal structure of the product a better internal agglomeration of particles which compact the material better as well.

\subsection{Technological studies}

\subsubsection{Wet condition}

The wet condition is a state in which a product is when formed, in this case, the process was pressing and for the research to each formulation it was added a percentage of dry water of $6,0 \pm 0,1 \%$ in weigh. Normally, this moisture will condition the properties of a ceramic product. As seen in Figure 5, the material has a low bulk density variability in wet, with increases ranging from $2,78 \%$ to $23,45 \%$. The F3, F6, and F7 show higher densification, indicating that at the time of exercising pressure to the material particles settled in a more uniform way into the structure of the specimens, this is because most materials had an outside diameter of fairly fine particle (Figure 2), which helped to be packaged much better internally; this can be checked by high increases in density generated formulations that also help to eliminate air trapped in the products and improve not only their strength but to decrease the percentage of breakage due to handling [26].

Confirming the data obtained in Figure 5; and due to the low variability in the bulk densi- 


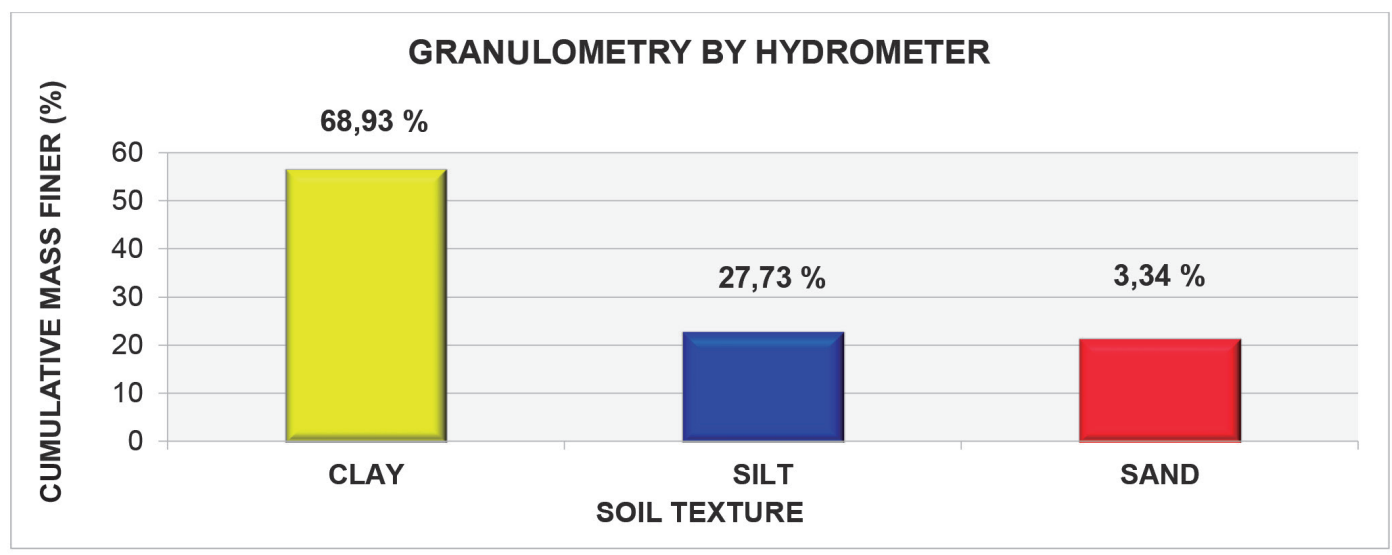

Figure 4. Particle size distribution of Clay.

Source: The authors.

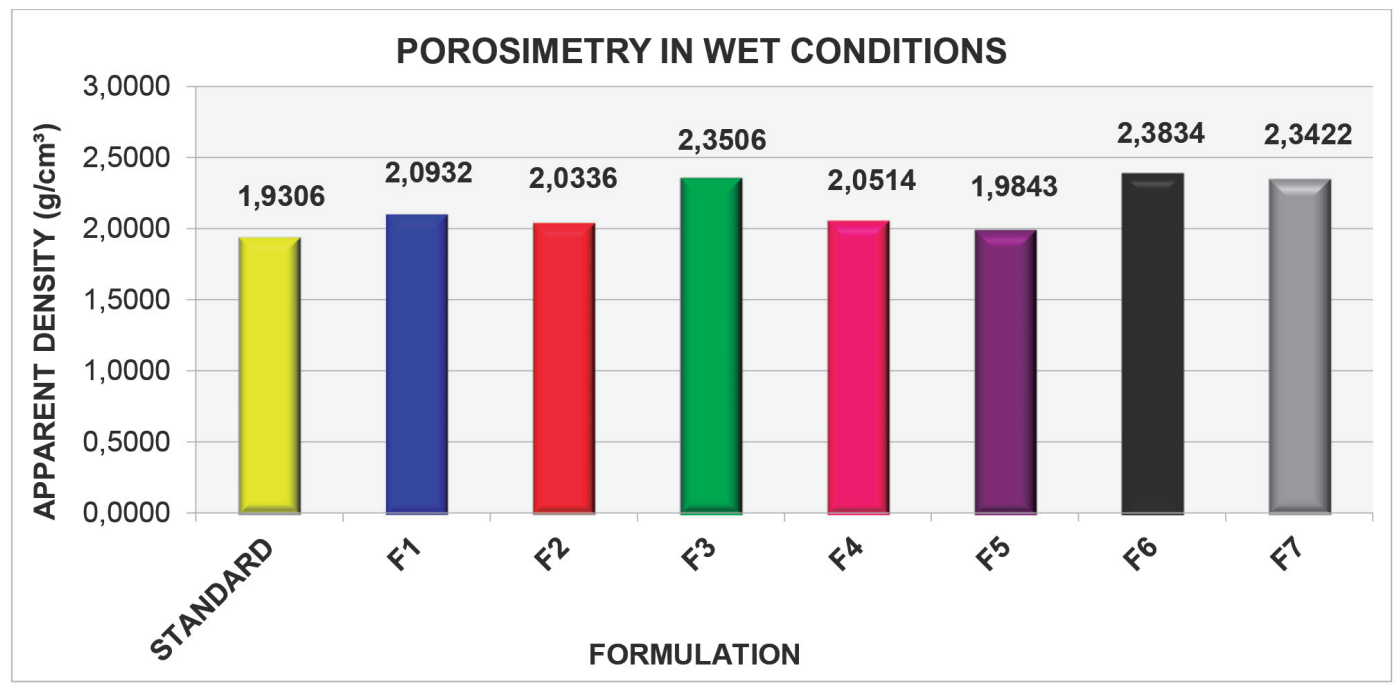

Figure 5. Mercury intrusion porosimetry in wet condition of the formulations.

Source: The authors

ty wet, detailed in Figure 6, the wet strength of most of the formulations have the same tendency, with a standard deviation of 0,051 ; it was observed that formulations F1 and F5 have higher flexural strength, increasing by $7,5 \%$ and $33,5 \%$ respectively over the standard formulation.

\subsubsection{Dry condition}

Figure 7 shows the test results of intrusion porosimetry of mercury made dry after $6 \mathrm{~h}$ in the oven at $110 \pm 5{ }^{\circ} \mathrm{C}$, this with the main objective of evaluating the pore system of the specimens and thus determine the material 
behavior by withdrawing water from its structure [27-28].

As you can see the F1, standard, and F5 formulations are the ones with higher density, indicating that the process of evaporation of water is best developed within these structures and that densification is performed better [29].

Figure 8 shows linear shrinkage in dry samples; excessive shrinkage can cause dimensional problems in the pieces and cracking, especial-

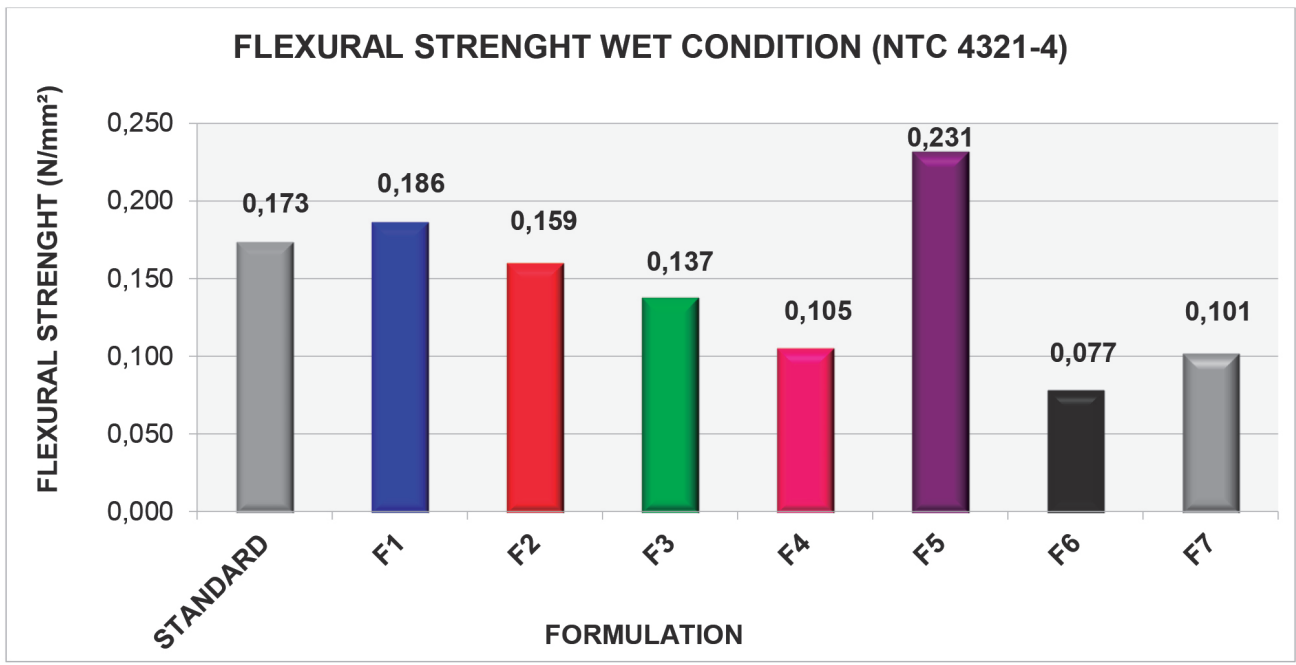

Figure 6. Flexural strength in wet condition of the formulations

Source: The authors.

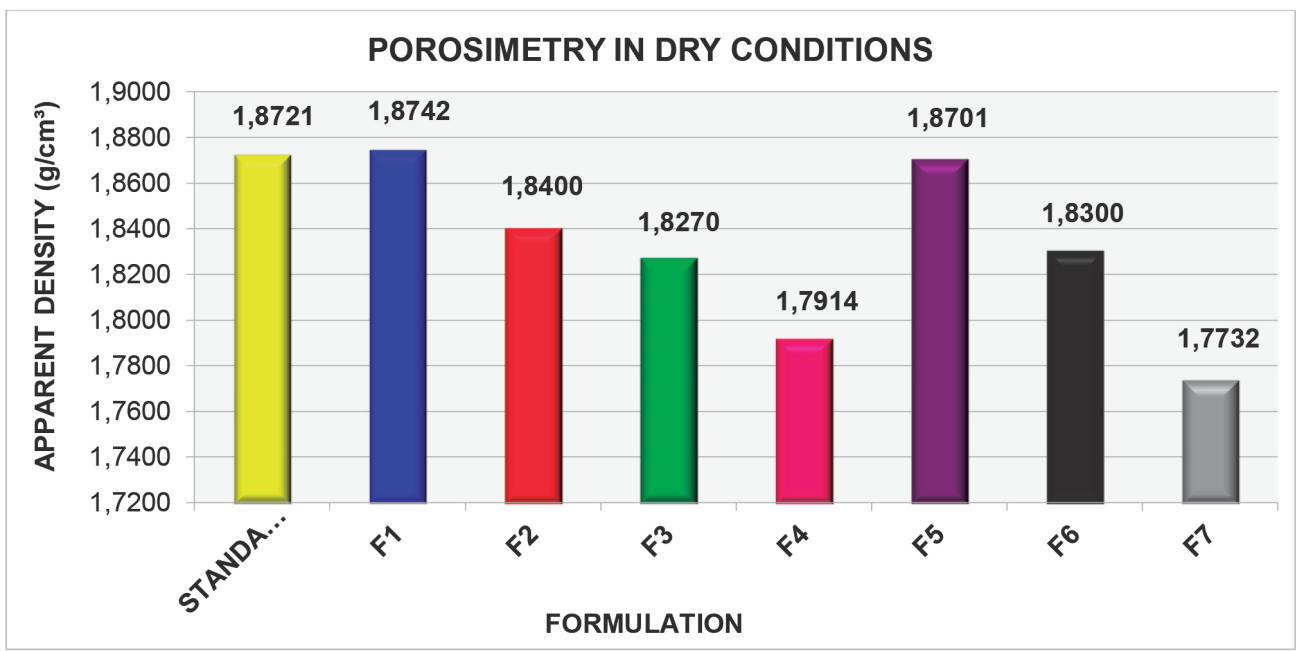

Figure 7. Mercury intrusion porosimetry in dry condition of the formulations.

Source: The authors. 
ly when you are manipulating the material. This property is associated mainly to several factors, like moisture present in the shaped samples, its mineralogical feature, the drying system used among others, but it directly affects the dry bulk density and this one, in turn, contraction [30].

As shown in Figure 8, the formulations that have greater contraction when dry are the $F 4$, $\mathrm{F} 5$, and $\mathrm{F} 7$, with an increase of $58,9 \%, 51,2 \%$ and $24,4 \%$ respectively compared to the standard formulation. However, reduced shrinkage to $8,3 \%$ is detailed in formulation $\mathrm{F} 3$ compared to the standard formulation, which indicates that with the addition of a high percentage of sand and clay it is caused a decrease in the control of this property, which influences the voltage differences that can occur during drying, mainly causing problems like cracks. In the formulations F4 and F7, typical behavior is observed regarding refers contraction. This because they are the ones with lower values of dry bulk density, $1,7914 \mathrm{~g} / \mathrm{cm}^{3}$ and
$1,7732 \mathrm{~g} / \mathrm{cm}^{3}$ respectively. F5 behavior can be attributed to the formulation having greater percentage of clay material with respect to others.

Figure 9 shows the average values of mechanical flexural strength in dry state obtained in the specimens tested. Series of 10 specimens were tested per formulation, where there was a standard deviation ranged in 0,049. It specifies that F1, F2, F5, F6, and F7 yield values above the standard formulation, increasing in $35,5 \%, 16,9 \%, 25,6 \%, 29,8 \%$ and $34,3 \%$ respectively.

High increases in F1, F2, F5, and F6 are characteristic of samples having a high density as observed in Figure 7 [31-32]. The high resistance value of $\mathrm{F} 7$ is probably due to high shrinkage dry $(0,209 \%)$ because it has the highest percentage of cement of all formulations, because as already mentioned, this material not only creates stability in the structure product but also acts on the clay by modifying its behavior,

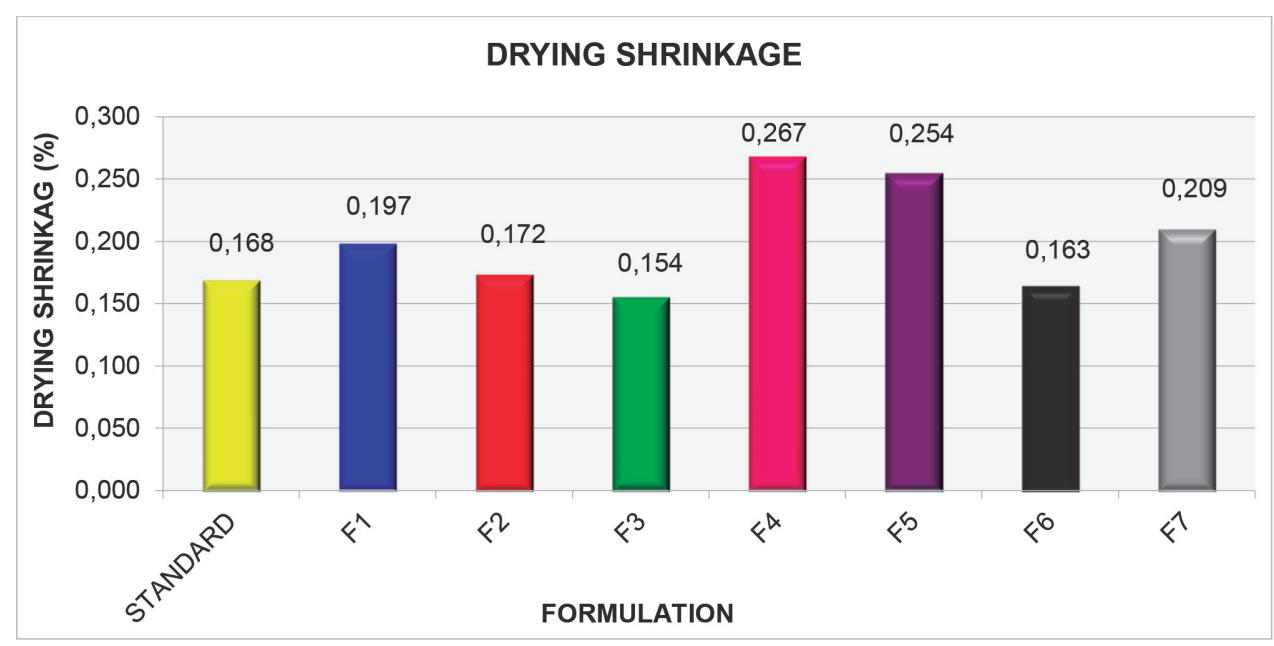

Figure 8. Linear shrinkage in dry formulations.

Source: The authors 


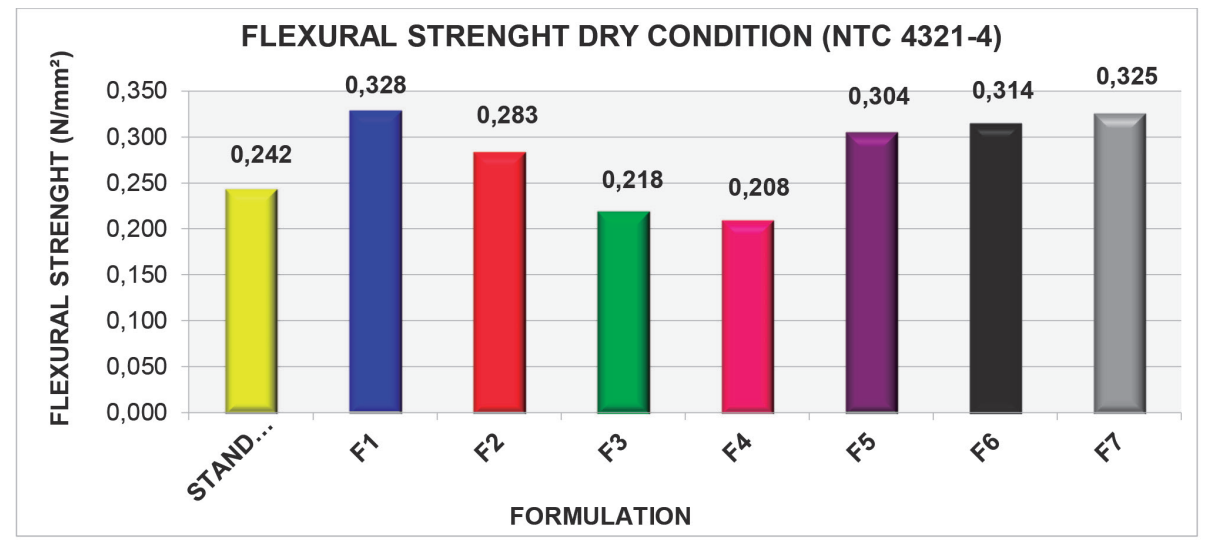

Figure 9. Flexural strength in dry condition formulations.

Source: The authors.

generating a structure difficult to alter and improving their mechanical strength [33].

Finally, it is shown in Figures 10 and 11 two characteristics that are critical when handling unsintered materials, the rate of pressability and post-pressing expansion [34]. The pressability index serves as an indicator to monitor problems of lack of compaction of the material after drying as well as to verify if the material is to generate cracks or breaks during handling, and post-press expansion serves to observe how the material behaves after removal from the socket mold and also whether the material could generate cracks in it by the force of repulsion of the particles [35].

As can be detailed in Figure 10, the formulations that better behave are $\mathrm{F} 6$ and $\mathrm{F} 7$, because they are above two, which is usually what is sought in the index pressability in a pressed material. This indicates that materials made from these two formulations will be less likely to generate cracks during the process and with the data of mechanical strength shown in Figure 9, we can deduce that they are the ones that will generate best structural stability making them able to use as structural units or as (dividing or closing) non-structural units, but with the quality of being unsintered materials it is recommended that they are used only as products of indoor units.

While Figure 11 shows the data obtained in the post-pressing expansion, in it the formulations that are not going to have a high degree of repulsion of the particles or tension at the edges of the pieces are detailed, while cracks generated in other materials with expansion above $0,8 \%$ are minimized [36].

\section{CONCLUSIONS}

The clay worked is a complex mixture of minerals including major structures like quartz, kaolinite, illite, and carbonates such as calcite; also, it presents values of alumina above $20 \%$, which makes it a commercially good material as it generates its glass at high temperatures and with its low content of alkali oxides and alkaline phases it can be used as a semi-re- 


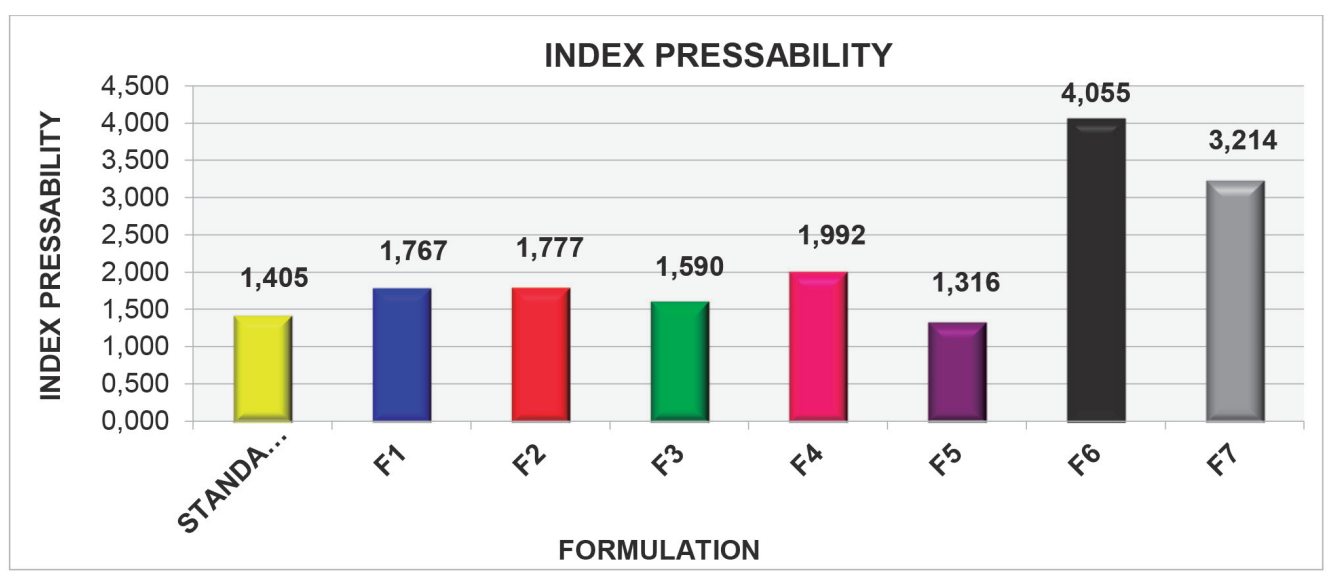

Figure 10. Index pressability formulations.

Source: The authors

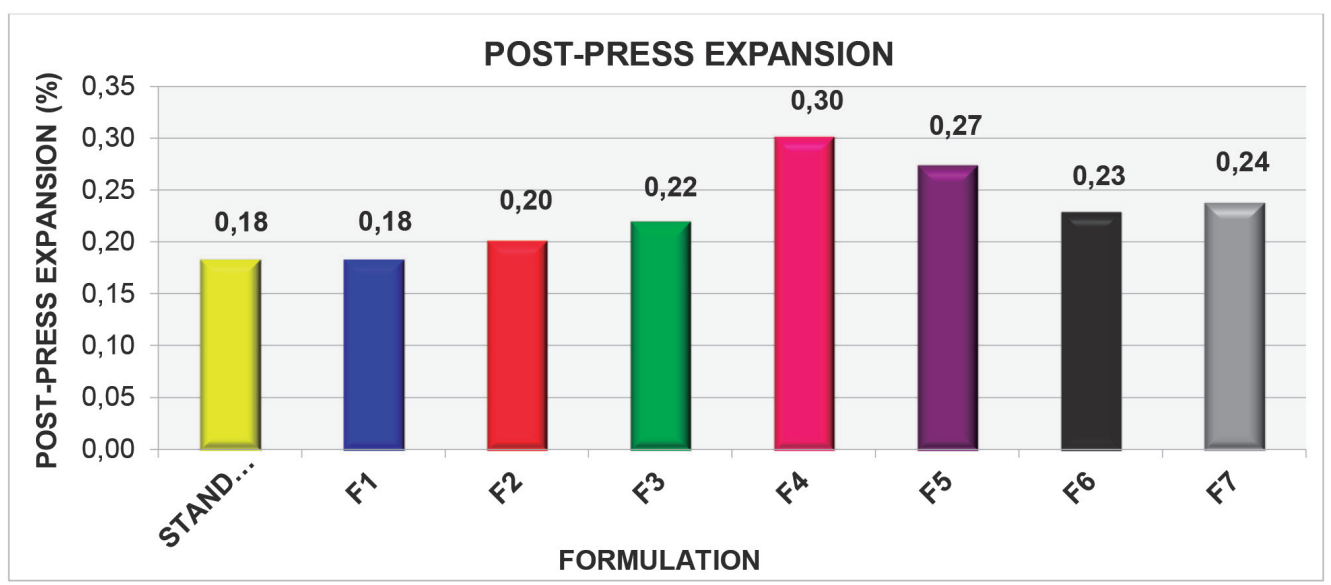

Figure 11. Post-pressing expansion formulations.

Source: The authors.

fractory material, but considering its red hue after cooking due to its iron content.

Non plastic materials had a very fine granulometry, which helped to better compaction of the specimens, considering that with the clayey nature of the plastic material the specimens used in the tests were better structurally packaged, resulting in an increase in densification with re- ference to standard paste, improving its mechanical strength and decreasing crack problems.

A high variability in the results of the dry density was not observed; what it was detailed was that the system of evaporation of moisture in the samples was better for those who had lower wet density, such as F1, F5, and F2 samples; no formulation presented dry shrinkage 
values above $0,3 \%$, which is the maximum dry contraction parameter a pressed product can have, indicating that the formulations will generate low rates of deformation during drying.

All dry formulations studied will behave better than the standard sample, but ultimately the F7 formulation was the one that got a much better repeatability of the results of the analyzes carried out, as it was its mechanical resistance flexion $\left(0,325 \mathrm{~N} / \mathrm{mm}^{2}\right)$, pressability index $(3,214)$, and dry contraction $(0,209 \%)$.

The use of materials such as cement, lime, and sand, improves performance of the dry clay, as observed in all research formulations; they performed better in all developed analysis, indicating that in an industrial field these materials can be used for manufacturing new products without the need for sintering, and thus help to reduce pollution, resources, and labor in the process.

\section{ACKNOWLEDGEMENT}

The authors express their gratitude to the Research Center of Ceramic Materials CIMAC from the Francisco de Paula Santander University, Cucuta-Colombia, for their support in conducting the tests.

\section{REFERENCES}

[1] Gonzalez I. (2001). Materias primas del área de Bailén. Impacto ambiental de explotaciones. Sociedad española de arcillas, 16(1), pp. 66-89.

[2] Sánchez C. J. (2001). El procesado cerámico. Sociedad española de arcillas, 16(1), pp. 96-115.
[3] Rozo-Rincón S. M., Sánchez-Molina J. \& Álvarez-Rozo D.C. (2014). Propiedades fisico mecánicas de bloques H10 fabricados en el área metropolitana de Cúcuta. Cienc. Ing. Neogranad., 24(1), pp. 67-78. doi: 10.18359/rcin.8

[4] American Society For Testing And Materials. (2011). ASTM C323-56 Standard test methods for chemical analysis of ceramic whiteware clays. ASTM, pp 1-5.

[5] American Society For Testing And Materials. (1998). ASTM D422-63 Standard test method for particle-size analysis of soils. ASTM, pp 1-8.

[6] American Society For Testing And Materials. (2003). ASTM C326-03 Standard Test Method for Drying and Firing Shrinkages of Ceramic Whiteware Clays. ASTM, pp. 1-2.

[7] Instituto Colombiano de Normas Técnicas y Certificación ICONTEC. (2005). NTC 4321-4 Baldosas cerámicas. Parte 4. Método de ensayo para determinar el módulo de rotura y la resistencia a la flexión. Bogotá, Colombia: ICONTEC.

[8] Instituto Colombiano de Normas Técnicas y Certificación ICONTEC. (2005). NTC 4113-2 Gestión ambiental. Calidad de suelo. Muestreo. Guía sobre técnicas de muestreo. Bogotá, Colombia: ICONTEC.

[9] American Society For Testing And Materials. (2014). ASTM C324-01 Standard test method for free moisture in ceramic whiteware clays. ASTM, pp. 1.

[10] American Society For Testing And Materials. (1998). ASTM D422 Particle size analysis of soils. ASTM, pp. 1-8. 
[11] Rodrigues-Filho R. (2007). El uso de la tierra como elemento constructivo en Brasil: un corto panorama del proceso histórico, manejo, usos, desafíos y paradigmas. Apuntes, 20(2), pp. 232-241.

[12] Gatani M.P. (2000). Ladrillos de suelocemento: Mampuesto tradicional en base a un material sostenible. Informes de la Construcción, 51(466), pp. 35-47. doi: 10.3989/ic.2000.v51.i466.713

[13] Begliardo H., Sánchez M., Panig M.C., Casenave S., \& Fornero G. (2006). Ladrillos de suelo-cemento elaborados con suelos superficiales y barros de excavación para pilotes. Ponencia. Mendoza, San Rafael, Argentina: Reciclado de residuos de construcción y demolición (RCD) y de residuos de procesos (RP)PROCQMA.

[14] Valle C. A. (2001). Durabilidad de ladrillos prensados de suelo-cemento. Materiales de Construcción, 51(262), pp. 15-21.

[15] Roseto O. (2006). Bloques con mezclas hipercomprimidas de suelo-cemento. Revista Cemento, 2 (7), pp. 11-13.

[16] Quille R. \& Bustamante A. (2013). Elaboración de pastas cerámicas de buena calidad a partir de materiales arcillosos en Perú. Tecnointi, pp. 1-2.

[17] Instituto Colombiano de Normas Técnicas y Certificación ICONTEC. (2005). NTC 4205 Unidades de mampostería de arcilla cocida. Ladrillos y bloques cerámicos. Bogotá, Colombia: ICONTEC.

[18] Galindo-Renau R. (2008). Prensas, moldes y prensado en la fabricación de baldosas cerámicas (Vol. I). Castellon de la Plana: Marcer S.L, pp. 1-381.

[19] American Society for Testing and Materials. (1996). ASTM D559-03: Standard test methods for wetting and drying compacted soil-cement mixtures. ASTM, pp. 1-6.

[20] Bernal I., Cabezas H., Espitia, C. \& J., M. \&. (2003). Análisis proximo de arcillas para cerámica. Rev. Acad. Colomb. Cienc, 27(105), pp. 569-578.

[21] Coelho C., Roqueiro N., \& Hotza D. (2002). Rational mineralogical analysis of ceramics. Mater. Lett, 52, pp. 394-398. doi: 10.1016/S0167-577X(01)00429-3

[22] Aleixandre-Ferrandis V., Gonzalez-Peña J. M. \& Sandoval del Rio F. (1974). Estudio fîsîcoquimico y tecnológico de un grupo de arcillas para ladrillería. Bol. Soc. Esp. Ceram. Vidr., 13(6), pp. 495-504.

[23] Vieira C., Sanchez R. \& Monteiro S. N. (2008). Characteristics of clays and properties of building ceramics in the state of Rio de Janeiro, Brazil. Constr Build Mater, 22(5), pp. 781-787. doi: 10.1016/j. conbuildmat.2007.01.006

[24] Ginés F., Feliu C., García-Ten J. \& Sanz V. (1997). Análisis de los métodos tradicionales utilizados para evaluar la plasticidad. Bol. Soc. Esp. Cerám. Vidrio, 36(1), pp. 25-30.

[25] Karkanis P.G., AU K. \& Schaalje G.B. (1991). Comparison of four measurement schedules for determination of soil particlesize distribution by the hydrometer method. Can Agr Eng, 33(2), pp. 211-215. 
[26] Amoros-Albaro J.L., Blasco-Fuentes A., Enrique-Navarro J.E. \& Negre-Medall F. (1987). Características de polvos cerámicos para prensado. Bol. Soc. Esp. Ceram. Vidr., 26(1), pp. 31-37.

[27] Amoros J.L., Bagan V., Orts M.J. \& Escardino A. (1988). La operación de prensado en la fabricación de pavimentos por monococción. I. Influencia de la naturaleza del polvo de prensas sobre las propiedades de las piezas en crudo. Bol. Soc. Esp. Ceram. Vidr., 27(5), pp. 273282.

[28] Jayasinghe S.N. \& Edirisinghe M.J. (2002). Effect of viscosityon the size of relics produced by electrostatic atomization. Aerosol Sci Tech, 33(10), pp. 1379-1388. doi: 10.1016/S0021-8502(02)00088-5

[29] Milheiro F.A., Freire M.N., Silva A.G. \& Holanda J. N. (2005). Densification behaviour of a red firing Brazilian kaolinitic clay. Ceram Int, 31(5), pp. 757-763. doi: 10.1016/j.ceramint.2004.08.010

[30] Escardino-Benlloch A., Amores-Albaro J. L. \& Enrique-Navarro J. E. (1981). Estudio de pastas de gres para pavimentos. Bol. Soc. Esp. Ceram. Vidr, 20(1), pp. 17-24.

[31] Sandoval F. \& Ibañez A. (2000). Discusión sobre la influencia de la porosidad en la resistencia mecánica de las baldosas cerámicas. Bol. Soc. Esp. Cerám. Vidr., 39(2), pp. 255-258.

[32] De Pablos A., Miranzo P., Osendi M.I., Bengochea M.A., Romero J.C., Gargallo L., y Crespo P. (2000). Estudio de las propiedades mecánicas de pavimentos cerámicos en crudo. Bol. Soc. Esp. Cerám.
Vidr., 39(5), pp. 631-634. doi: 10.3989/ cyv.2000.v39.i5.781

[33] Sandoval del Río F., \& González-Peña J.M. (s.f.). (1981). La arcilla ilitica en la obtención de porcelanas de alta resistencia mecánica. I. materias primas. Bol. Soc. Esp. Ceram. Vidr., 20(2), pp. 105112.

[34] Amoros J.L., Feliu C., Cines F. \& Mestre S. (1994). La extracción de la pieza del molde durante la fase de prensado. Influencia de algunas variables de operación. Bol. Soc. Esp. Cerám. Vidr., 33(4), pp. 207-211.

[35] De Aza Pendas S. (1964). Defectos de prensado. Bol. Soc. Esp. Cerám. Vidr., 3(4), pp. 395-416.

[36] SACMI \& Cerámicos A. E. (2004). Tecnología cerámica aplicada (Vol. I). Italia: Faenza Editrice Ibérica, S.L, pp. 1-446. 